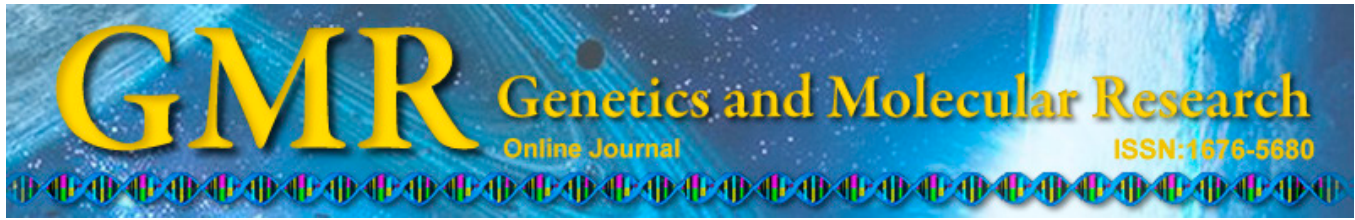

\title{
Pdxl and its role in activating Ngn3 and Pax6 to induce differentiation of iPSCs into islet $\beta$ cells
}

\author{
Y. Qin ${ }^{1,2}$, L. Xiao ${ }^{2,3}$, X.B. Zhan ${ }^{2}$ and H.X. Zhou ${ }^{1,2}$ \\ ${ }^{1}$ Anhui Medical University, Hefei, Anhui, China \\ ${ }^{2}$ Department of Surgery, Shenzhen Second People's Hospital, \\ Shenzhen, Guangdong, China \\ ${ }^{3}$ Biological Therapy, Shenzhen Second People's Hospital, \\ Shenzhen, Guangdong, China \\ Corresponding author: H.X. Zhou \\ E-mail: zhouhanxin_zhx@163.com
}

Genet. Mol. Res. 14 (3): 8892-8900 (2015)

Received December 17, 2014

Accepted April 28, 2015

Published August 3, 2015

DOI http://dx.doi.org/10.4238/2015.August.3.12

ABSTRACT. The pancreatic and duodenal homeobox factor $1(\mathrm{Pdx} 1)$
protein is the most pivotal transcription factor in the development of
islet $\beta$ cells. This study investigated the role of Pdx 1 and its mechanism
in differentiating induced pluripotent stem cells (iPSCs) into islet $\beta$
cells. iPSCs derived from human skin fibroblasts were cultured in vitro
and directionally induced to differentiate for 20 days. The expression
of insulin-related genes was then detected by RT-PCR, and the
expression of several differentiation-related transcription factors was
assessed both before and after the differentiation process. Lastly, the
specific promoter regions where Pdx 1 binds were detected by ChIP. The
insulin-related genes, MafA, insulin, Glut2, Nkx6.1, GCK, and Tcf1,
showed increased expression during differentiation, and nearly peaked
on the 20th day. Similarly, the expression of transcription factors, Pdx1,
Ngn3, and Pax6 showed enhanced expression during differentiation as
compared with that of the control group. ChIP experiments confirmed 
that $\mathrm{Pdx} 1$ activates the expression of the downstream transcription factors, Ngn3 and Pax6, by combined with the promoter regions of insulin (Insulin-P), Ngn3 (Ngn3-P), and Pax6 (Pax6-P). In conclusion, $\mathrm{Pdx} 1$ activates downstream transcription factors Ngn3 and Pax6, and may be one of the mechanisms that promote differentiation of iPSCs into islet $\beta$ cells.

Key words: Induced pluripotent stem cell; islet $\beta$ cells; Insulin; Pancreatic and duodenal homeobox factor 1; Neurogenin 3; Paired box gene 6

\section{INTRODUCTION}

Diabetes is a common disease that is associated with many serious complications. Pancreas transplantation is one way to treat diabetes, but a shortage in donors and immunological rejection of the transplanted tissue limit its use (Hecht et al., 2009). Islet $\beta$ cells are the only cells responsible for the transport, synthesis, and release of insulin. Insulin is the hormone that acts to lower blood sugar, and regulate peripheral blood sugar levels.

The development and differentiation of islet $\beta$ cells in the embryo are regulated by multiple transcription factors, and the molecular mechanisms behind this developmental process are essential for diabetes research. Given this fact, we attempted to follow the molecular changes during the differentiation of induced pluripotent stem cells (iPSCs) into pancreatic islet $\beta$ cells. Specifically, RT-PCR was used to detect the expression of pancreatic and duodenal homeobox factor 1 (Pdx1), neurogenin 3 (Ngn3), paired box gene 6 (Pax6), and other important transcription factors both before and after the differentiation process. Moreover, Pdx1 binding sites on DNA promoter regions were detected by chromatin immunoprecipitation (ChIP). These experiments were aimed at determining the specific role and mechanism of $\operatorname{Pdx} 1$ in the differentiation of iPSCs into islet $\beta$ cells.

\section{MATERIAL AND METHODS}

\section{Culture of iPSCs derived from human skin fibroblasts}

iPSCs derived from human skin fibroblasts (purchased from Guangzhou Institute of Biomedicine and Health, Chinese Academy of Sciences) were cultured in the TeSR-E8 medium (STEMCELL Technologies Inc., Canada) for human embryonic stem cells (ES cells) containing Matrigel Matrix (BD Company, America) without a feeder layer, and placed in a $5 \% \mathrm{CO}_{2}$ incubator at $37^{\circ} \mathrm{C}$. Cells were typically grown to $90 \%$ or more, after which they were treated with Dispase II (Gibco, Life Technologies, Thermo Fisher Scientific Inc.) to passage the cells. Cultured iPSCs were observed by inverted microscope and photographed.

\section{iPSC differentiation}

When iPSCs were grown to more than $90 \%$ or more, they were digested using $200 \mathrm{U} /$ $\mathrm{mL}$ Collagenase IV for $4 \mathrm{~min}$ at $37^{\circ} \mathrm{C}$. Cells were then separated into single cells, and undif- 
ferentiated cells were pelleted, seeded on a Petri dish, and covered with Matrigel Matrix. Cells were grown until 60\%, and then cultured for 4 days in Dulbecco's Modified Eagle Medium (DMEM)/F12 medium containing 0.2\% bovine serum albumin (BSA), N2 (1:50), B27 (1:50), $100 \mathrm{ng} / \mathrm{mL}$ activin $\mathrm{A}$, and $1 \mu \mathrm{M}$ wortmannin. These cells were then cultured for an additional 4 days in F12/Iscove's Modified Dubecco's Medium containing 0.5\% BSA, 0.5\% Insulin Transferrin Selenium (ITS), B27 (1:50), $2 \mu \mathrm{M}$ retinoic acid, $20 \mathrm{ng} / \mathrm{mL}$ fibroblast growth factor 7 , and $50 \mathrm{ng} / \mathrm{mL}$ Noggin, subsequently, these cells were cultured for 5 days in DMEM high glucose medium containing $0.5 \%$ BSA, $1 \%$ ITS, N2 (1:100), and $50 \mathrm{ng} / \mathrm{mL}$ epidermal growth factor. Finally, these cells were cultured for another 7 days in DMEM/F12 medium containing $1 \%$ ITS, $10 \mathrm{ng} / \mathrm{mL}$ basic fibroblast growth factor, $10 \mathrm{mM}$ nicotinamide, $50 \mathrm{ng} / \mathrm{mL}$ exendin- 4 , and $10 \mathrm{ng} / \mathrm{mL}$ Bone morphogenetic protein 4 , to promote cell maturation.

\section{Primer design}

The primers used in this study were: glyceraldehyde-3-phosphate dehydrogenase (GAPDH) (F: 5'-ATCTTCCAGGAGTGAGCGAGA-3', R: 5'-ACTGACACGTTGGCAGTG G-3'; produces a 504-bp product), Pdx1 (F: 5'-CAAAGCTCACGCGTGGAAAG-3', R: 5'-TTTTTCCACTTCATGCGGCG-3'; produces a 234-bp product), NGN3 (F: 5'-CTCAGGA AATCCCTGCGGTC-3', R: 5'-CATCCTTTCTACCGGCGCAA-3'; produces a 216-bp product), Pax6 (F: 5'-GTCGGTAAAGCTAGCTGGTT-3', R: 5'-CGTTTAGGCAACCCGGCTTA-3'; produces a 318-bp product), insulin-promoter (F: 5'-GACTATAAAGCCAGCGGGGG -3', R: 5'-CCTGCTTGATGGCCTCTTCT-3'; produces a 76-bp product, Ngn3-promoter (F: 5'-TGCCACTATCTTCCTGTGCG-3', R: 5'-CAGCAACTCTCGGTTCCTCA-3'; produces a 225-bp product), GAPDH-promoter (F: 5'-TACTAGCGGTTTTCGGGG-3', R: 5'-TCGAACA GGAGCAGAGAGCG-3'; produces a 166-bp product), Pax6-promoter (F: 5'-GCTAATTTAG GCATCACGGA-3', R: 5'-CTGAGCGGATCAGCATAGCC-3'; produces a 221-bp product).

\section{RT-PCR}

\section{RNA extraction}

In this experiment, control cells, which were those iPSCs before the induction of differentiation, are termed group A, while the experimental group, which are those iPSCs that had been differentiated into islet $\beta$ cells, were termed group B. In either case, $1 \times 10^{6}$ cells from each group were removed from medium, washed twice in cold PBS, and added to $1 \mathrm{~mL}$ TRIzol. These samples were placed at room temperature for 5-10 min, after which 0.2 volumes of chloroform were added. Subsequently, these samples were centrifuged at 12,000 $\mathrm{g}$ for $15 \mathrm{~min}$ at $4^{\circ} \mathrm{C}$.

Following centrifugation, the aqueous layer was removed and placed in a clean test tube. We then added 0.5 volumes of isopropanol, mixed, and incubated the samples at room temperature for $15 \mathrm{~min}$. These samples were then centrifuged at $12,000 \mathrm{~g}$ for $10 \mathrm{~min}$ at $2^{\circ}-8^{\circ} \mathrm{C}$. Following centrifugation the upper layer was removed and the RNA precipitate was washed with $1 \mathrm{~mL} 75 \%$ ethanol, mixed on the shaker, and centrifuged at $7500 \mathrm{~g}$ for $5 \mathrm{~min}$ at $2^{\circ}-8^{\circ} \mathrm{C}$, The supernatant was then discarded, and the RNA precipitate was air dried. The pellet was then resolubilized in RNase-free water. 


\section{cDNA synthesis $20-\mu L$ system}

To synthesize cDNA, we prepared a $100 \mu \mathrm{L}$ Eppendorf tube, and successively added 1 $\mu \mathrm{L}$ RNA, $1 \mu \mathrm{L}$ oligo primer, and deionized water to a total volume of $12 \mu \mathrm{L}$ on ice. This sample was mixed gently, spun-down, and incubated for $5 \mathrm{~min}$ at $65^{\circ} \mathrm{C}$. After the incubation we successively added $4 \mathrm{~mL} 5 \mathrm{X}$ reaction buffer, $1 \mu \mathrm{L} 20 \mathrm{U} / \mu \mathrm{L}$ RNA inhibitor, $2 \mu \mathrm{L} 10 \mathrm{mmol} / \mu \mathrm{L}$ dNTP, and $1 \mu \mathrm{L} 200 \mathrm{U} / \mu \mathrm{L}$ reverse transcriptase RevertAid M-MuLV to the sample. This sample was then gently mixed, spun-down, and incubated for $60 \mathrm{~min}$ at $42^{\circ} \mathrm{C}$. The sample was then incubated for $10 \mathrm{~min}$ at $70^{\circ} \mathrm{C}$, after which the reaction was terminated and the cDNA was obtained.

\section{PCR}

The components for the PCRs were: $2 \mu \mathrm{L}$ template cDNA, $1 \mu \mathrm{L}$ Primer A, $1 \mu \mathrm{L}$ Primer B, $0.5 \mu \mathrm{L}$ Taq enzyme, $5 \mu \mathrm{L}$ 10X buffer, $1 \mu \mathrm{L} 10 \mathrm{mM}$ dNTP mix, $25 \mathrm{mM} \mathrm{MgCl}$, and $\mathrm{ddH}_{2} \mathrm{O}$ added to a total volume of $50 \mu \mathrm{L}$. Once complete, this solution was placed in a PCR machine under the following program: $92^{\circ} \mathrm{C}$ for $2 \mathrm{~min}, 92^{\circ} \mathrm{C}$ for $30 \mathrm{~s}, 59^{\circ} \mathrm{C}$ for $30 \mathrm{~s}$, and $72^{\circ} \mathrm{C}$ for $45 \mathrm{~s}$, for a total of 30 cycles. Following the last cycle, the sample was subjected to a 2-min incubation at $72^{\circ} \mathrm{C}$. Samples were then preserved at $4{ }^{\circ} \mathrm{C}$. A $2 \%$ agarose gel was used to assess the amplified product.

\section{ChIP of iPSCs}

iPSCs were grown to $80 \%$, removed from medium, and washed once with $10 \mathrm{~mL} 1 \mathrm{X}$ PBS. These cells were then washed with $10 \mathrm{~mL} 1 \mathrm{X}$ PBS plus $1 \%$ formaldehyde and rotated for $20 \mathrm{~min}$ at room temperature. After this time, cross-linking was terminated with $0.125 \mathrm{M}$ glycine, and the cells were rotated for $10 \mathrm{~min}$ at $4^{\circ} \mathrm{C}$. Following this incubation, the PBS solution was discarded and cells were washed twice with ice-cold PBS, and collected with a cell scraper into $15 \mathrm{~mL}$ centrifuge tubes. These cells were then centrifuged at $2000 \mathrm{~g}$ for $5 \mathrm{~min}$ to collect cells.

The supernatant was removed and SDS Lysis Buffer (containing $50 \mathrm{mM}$ Tris, $\mathrm{pH}$ $8.1,1 \%$ SDS, sodium pyrophosphate, $\beta$-glycerophosphate, sodium orthovanadate, sodium fluoride, EDTA, leupeptin) plus protease inhibitors was added to the cell pellet to a final cell concentration of $1 \times 10^{6} \mathrm{cells} / 100 \mu \mathrm{L}$. Cells were then disrupted on ice using ultrasonic energy ( $30 \%$ of the maximum output, $10 \mathrm{~s}$ each time for a total of 20 times, an interval of $1 \mathrm{~min}$ each time). Samples were then centrifuged at $12,000 \mathrm{~g}$ for $10 \mathrm{~min}$ at $4^{\circ} \mathrm{C}$.

One hundred microliters of whole-cell extract was added $900 \mu \mathrm{L}$ ChIP dilution buffer (50 mM Tris-HCL, pH 8.0, $1 \mathrm{mM}$ EDTA, 1\% SDS, $50 \mathrm{mM} \mathrm{NaHCO}_{3}$ ) and $60 \mu \mathrm{L}$ Protein $\mathrm{G}$ agarose, and gently mixed for $60 \mathrm{~min}$ at $4^{\circ} \mathrm{C}$. The sample was then centrifuged for $1 \mathrm{~min}$ at $4^{\circ} \mathrm{C}$ at $6000 \mathrm{~g}$. The supernatant was removed divided into three $1.5-\mathrm{mL}$ centrifuge tubes (labeled as negative control, positive control, input group), where $5 \mu \mathrm{g}$ rabbit IgG and anti-Pdx 1 rabbit antibody were added, respectively. These samples were then rotated and incubated at $4{ }^{\circ} \mathrm{C}$ overnight.

Following the incubation, $60 \mu \mathrm{L}$ protein $\mathrm{G}$ Sepharose was added to the solutions and incubated for $60 \mathrm{~min}$ at $4^{\circ} \mathrm{C}$, after which samples were centrifuged at $7000 \mathrm{~g}$ for $1 \mathrm{~min}$ at $4^{\circ} \mathrm{C}$. The resulting supernatants were discarded.

Pellets were washed with $1 \mathrm{~mL}$ low salt wash buffer $(0.1 \%$ SDS, $1 \%$ Triton X-100, 2 mM EDTA, $20 \mathrm{mM}$ Tris-HCl, pH 8.0, $150 \mathrm{mM} \mathrm{NaCl})$, high salt wash buffer $(0.1 \%$ SDS, $1 \%$ 
Triton X-100, $2 \mathrm{mM}$ EDTA, $20 \mathrm{mM}$ Tris-HCl, pH 8.0, $500 \mathrm{mM} \mathrm{NaCl}$ ), and $\mathrm{LiCl}$ wash buffer ( $0.25 \mathrm{M} \mathrm{LiCl}, 1 \% \mathrm{NP}-40,1 \% \mathrm{SDC}, 1 \mathrm{mM}$ EDTA, $10 \mathrm{mM}$ Tris-HCl, $\mathrm{pH}$ 8.0). Lastly, the samples were washed twice with TE wash buffer $(10 \mathrm{mM}$ Tris-HCl, $\mathrm{pH} 8.0,1 \mathrm{mM}$ EDTA, $\mathrm{pH}$ 8.0) and centrifuged at $7000 \mathrm{~g}$ for $1 \mathrm{~min}$ at $4^{\circ} \mathrm{C}$. The resulting supernatant was discarded.

One hundred microliters of freshly prepared ChIP extracting solution (1\% SDS, 0.1 $\mathrm{M} \mathrm{NaHCO}_{3}$ ) was added to the precipitate and incubated for $15 \mathrm{~min}$ at room temperature. Subsequently, the samples were centrifuged at $7000 \mathrm{~g}$ for $1 \mathrm{~min}$ at $4^{\circ} \mathrm{C}$. The resulting supernatant was removed and placed in another centrifuge tube. This procedure was repeated one more time and the supernatants were combined.

To this solution, we added $8 \mu \mathrm{L} 5 \mathrm{M} \mathrm{NaCl}$ and incubated the solution at $65^{\circ} \mathrm{C}$ for 5 h. One microliter of $10 \mathrm{~g} / \mathrm{L}$ RNase A solution was then added and the samples were then incubated at $37^{\circ} \mathrm{C}$ for $30 \mathrm{~min}$. The resulting solution was then treated with $4 \mu \mathrm{L} 0.5 \mathrm{M}$ EDTA, $8 \mu \mathrm{L} 1 \mathrm{M}$ Tris- $\mathrm{HCl}, \mathrm{pH} 6.5$, and $1 \mu \mathrm{L} 10 \mathrm{mg} / \mathrm{mL}$ proteinase $\mathrm{K}$ for $2 \mathrm{~h}$ at $45^{\circ} \mathrm{C}$. Following this incubation, $1 \mathrm{~mL}$ binding buffer ( $4.5 \mathrm{M}$ guanidine isothiocyanate, $0.5 \mathrm{M}$ potassium acetate, $\mathrm{pH}$ 5.0) was added to the samples. A DNA combination column was then used to isolate the DNA, and samples were centrifuged through the column at $12,000 \mathrm{~g}$ for $30 \mathrm{~s}$. The column was then washed with washing buffer $(10 \mathrm{mM}$ potassium acetate, $\mathrm{pH} 5.0,80 \%$ ethanol, 16.7 $\mu \mathrm{M}$ EDTA, pH 8.0) twice, and DNA was eluted with $50 \mu \mathrm{L}$ elution buffer (10 mM Tris-Cl, $\mathrm{pH} 8.5)$.

\section{Statistical analysis}

Data were analyzed by SPSS 17.0. Measurement data are reported as means \pm standard deviation. Comparisons were performed using the Student $t$-test in two groups and were performed using ANOVA among multiple groups. $\mathrm{P}<0.05$ was considered to be statistically significant.

\section{RESULTS}

\section{Differentiation of iPSCs into islet $\beta$ cells}

iPSCs derived from human skin fibroblasts were cultured successfully in vitro (Figure 1A). After the induction of differentiation, these cells were observed under a microscope on day 4, 8, 13, and 20. We found that cell morphology and distribution changed (Figure 1B-E). During the induction of differentiation, the expression of insulin-related genes MafA, insulin, Glut2, Nkx6.1, GCK, and Tcf were measured every 2 days. We found that the expression of all of these genes increased and peaked on the 20th day after the initiation of differentiation (Figure 1F), indicating that mature islet $\beta$ cells have been formed.

\section{Expression of $P d x 1, N g n 3$, and $P$ ax6 in differentiated pancreatic $\beta$ cells}

RT-PCR showed that the expression of $P d x 1, N g n 3$, and Pax6 in group B was significantly enhanced as compared to group A (Figure 2), suggesting enhanced expression of $P d x 1$ activated downstream genes Ngn 3 and Pax6. The expression of Ngn 3 and Pax6 increased after iPSCs differentiated into islet $\beta$ cells. 

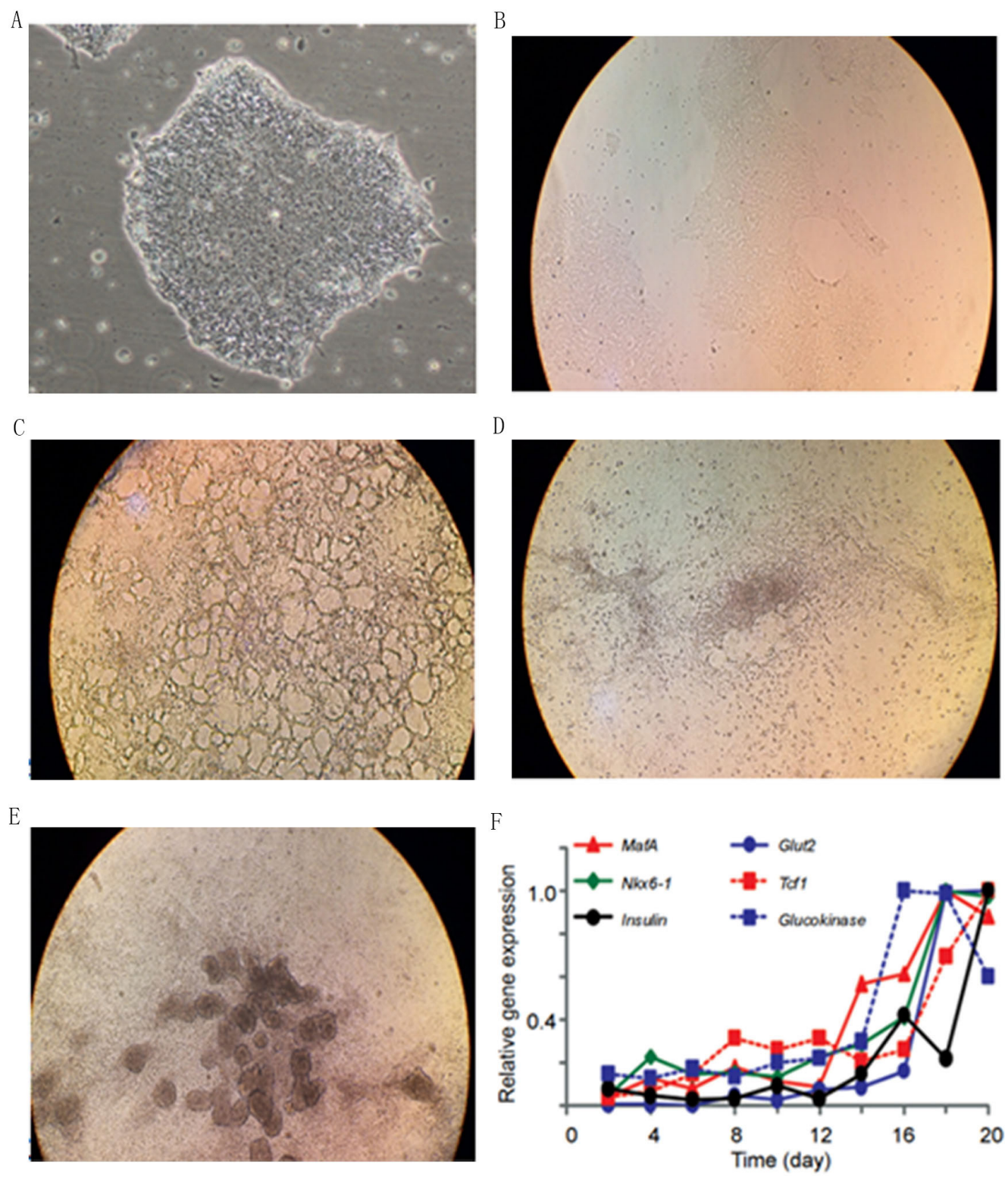

Figure 1. iPSCs induced to differentiate into islet $\beta$ cells. A. Before induction, the growth of iPSCs is good and dense (20X magnification). B. Four days after differentiation was induced the cell shape changes and the differentiation into pancreatic cells begins (20X magnification). C. Eight days after differentiation was induced, the cells began to differentiate into progenitor cells (20X magnification). D. Thirteen days after differentiation was induced, the number of progenitor cells grew significantly (4X magnification). E. Twenty days after differentiation was induced, the progenitor cells differentiated into islet $\beta$-like cells (4X magnification). F. Expression of the insulin-related genes in differentiated pancreatic $\beta$ cells. 


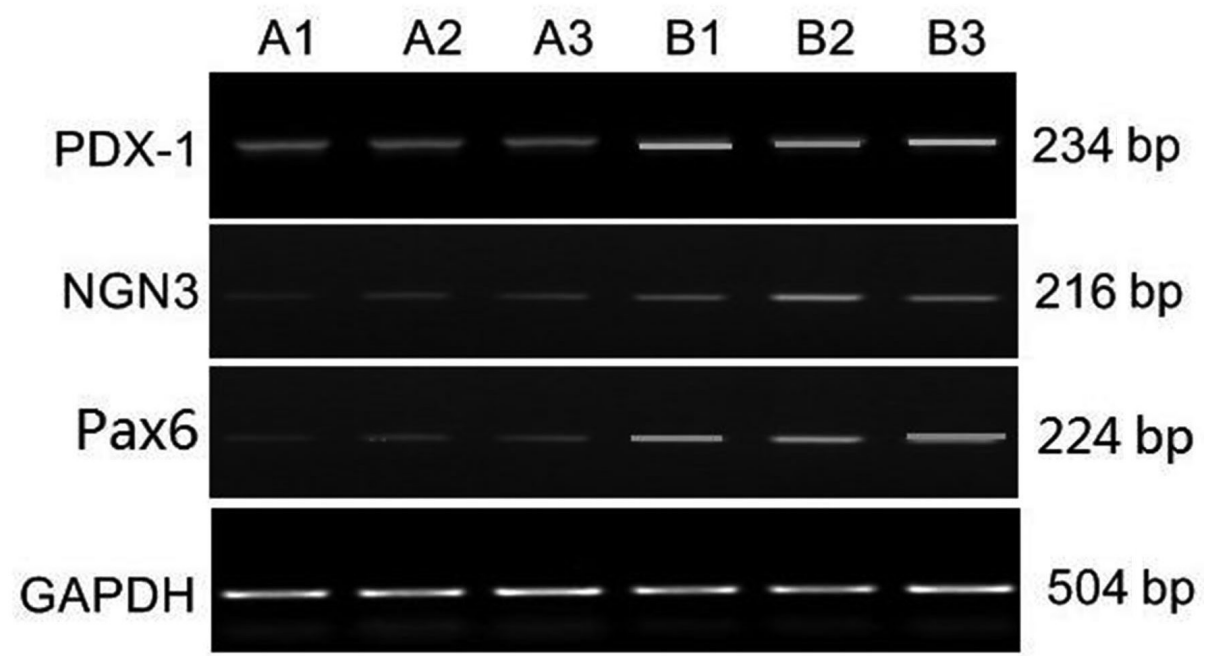

Figure 2. Expression of insulin-related genes $P d x 1, N g n 3$, and Pax6 in Groups A and B.

\section{Role of Pdx1 in the differentiation of iPSCs into islet $\beta$ cells}

The DNA obtained from the Pdx1 ChIP was analyzed by PCR using the primers specific to the promoter regions of insulin (Insulin-P), Ngn3 (Ngn3-P), and Pax6 (Pax6-P) genes. Results indicated that fragments obtained corresponded to the target regions with no nonspecific amplification (Figure 3). Described Pdx1 antibody precipitated DNA fragment contained Insulin, Ngn3 and Pax6 gene sub-region. It is suggested that Pdx1 promotes differention of iPSCs into islet $\beta$-like cells by activating insulin, Ngn3, and Pax6 expression.

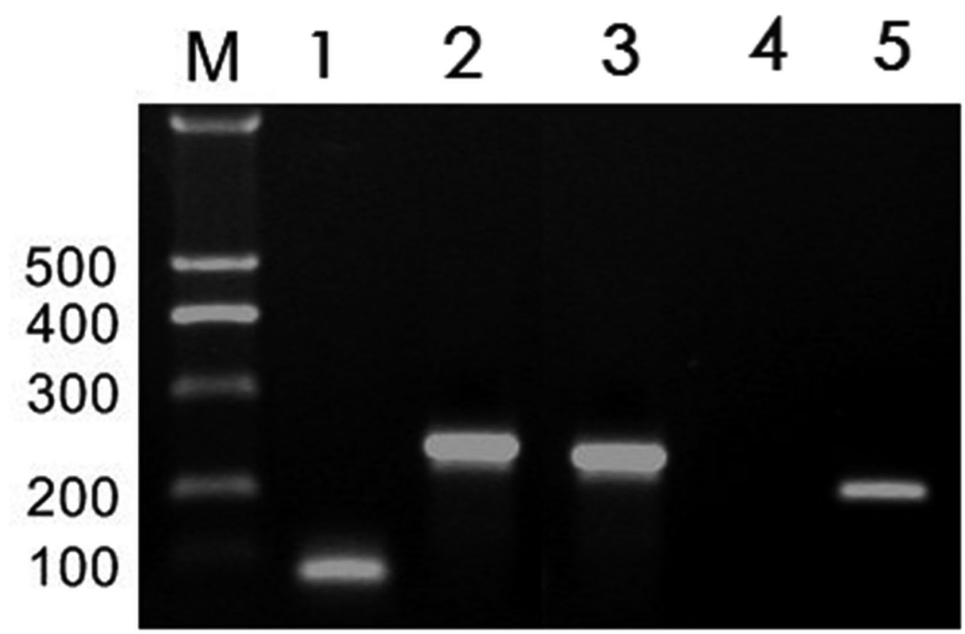

Figure 3. PCR amplification of the promoter regions for the insulin, Ngn3, and Pax6 genes following Pdx1 ChIP. Lane 1 = Insulin-P, lane 2 = Ngn3-P, lane $3=$ Pax6-P, lane $4=$ negative control, and lane $5=$ internal control GAPDH; lane $M=$ DNA ladder. 


\section{DISCUSSION}

Studies have shown that $\mathrm{Pdx} 1$ is the most important transcription factor in the process of directional differentiation and maturation of the pancreas. It is necessary for pancreatic bud formation during the embryonic period and the subsequent differentiation of islet $\beta$ cells (Guz et al., 1995). Pdx1 is known to directly bind to the insulin gene promoter region (Ashizawa et al., 2004), which is consistent with our results. In addition to Pdx1, epithelial cells that have further differentiated into pancreatic $\beta$ cells require the interaction of a series of transcription factors such as Ngn3 and Pax6 to drive maturation into islet $\beta$ cells (Serafimidis et al., 2008).

Ngn3 is not expressed in pancreatic progenitor cells, but becomes expressed in endocrine progenitor cells (Jiang and Morahan, 2012). It is speculated that Ngn3 acts as a switch in regulating the pancreatic development process. Wang et al. (2009) confirmed that in rat embryonic development and adult pancreatic islet repair, the expression of Ngn3 decreased. Moreover, the expression of related genes (NeuroD1, Nkx2.2, and Pax6), which are located at downstream of $\mathrm{Ngn} 3$ and regulate islet cell differentiation and maturation, will also be reduced, and eventually lead to islet endocrine dysfunction.

Pancreatic differentiation of the endoderm requires Pax6 participation, which together with the other key transcription factors plays an important role in the processes of pancreatic morphopoiesis and regulating pancreatic islet $\beta$ cell development (Laakso, 2009). St-Onge et al. (1997) have shown that Pax6 is expressed during early pancreatic development and maturation of endocrine cells. Moreover, if Pax6 is deleted then pancreatic endocrine cell development will be subject to developmental dysfunction.

Yuan et al. (2010) have shown that transcription factors Pdx1 and Ngn3 can activate other downstream transcription factors and have a synergistic effect in the process of pancreatic endocrine cell development. Oliver-Krasinski et al. (2009) indicated that Pdx1 could activate Ngn3 and the crossover network of downstream transcription factors, making ES cells or pancreatic progenitor cells differentiate into pancreatic islet $\beta$ cells.

The experiments conducted in this study confirmed that in vitro iPSCs were capable of differentiating into islet $\beta$-like cells, and that the expression of the transcription factors Pdx 1 , Ngn3, and Pax6 were significantly enhanced in this process. Furthermore, ChIP experiments indicated that Pdx 1 activates Ngn3 and Pax6 expression by binding to their respective promoter regions, which further activates downstream gene networks and promotes iPSCs to differentiate into islet $\beta$ cells. Accordingly, we speculate that Pdx 1 activates Ngn3 and starts the expression of downstream transcription factor Pax6, thereby promoting iPSCs to differentiate into islet $\beta$ cells. However, numerous questions remain, such as whether Pdx 1 activates these genes simultaneously, inhibits other transcription factors after Pdx 1 activates Ngn3, or plays the role in multiple signaling pathways.

\section{Conflicts of interest}

The authors declare no conflict of interest.

\section{ACKNOWLEDGMENTS}

Research supported by the Shenzhen Special Fund for the Development of Strategic Emerging Industry (project \#JCYJ20120614085530935); the Shenzhen Knowledge 
Innovation Program (project funds \#JCYJ20130401114114947, \#JCYJ20130401114225775); the Project of Science and Technology of Shenzhen (Technological Innovation Project: \#CXZZ20120614154434310); and the Plan of the Construction of Innovative Environment in Shenzhen (Key Laboratory: \#ZDSY20130531165409949).

\section{REFERENCES}

Ashizawa S, Brunicardi FC and Wang XP (2004). Pdx-1 and the pancreas. Pancreas 28: 109-120.

Guz Y, Montminy MR, Stein R, Leonard J, et al. (1995). Expression of murine STF-1, a putative insulin gene transcription factor, in cells of pancreas, duodenal epithelium and pancreatic exocrine and endocrine progenitors during ontogeny. Development 121: 11-18.

Hecht G, Eventov-Friedman S, Rosen C, Shezen E, et al. (2009). Embryonic pig pancreatic tissue for the treatment of diabetes in a nonhuman primate model. Proc. Natl. Acad. Sci. U. S. A. 106: 8659-8664.

Jiang FX and Morahan G (2012). Pancreatic Stem Cells: From Possible to Probable. Stem Cell Rev. 8: 647-657.

Laakso M (2009). PAX6 and glucose metabolism. Diabetologia 52: 381-384.

Oliver-Krasinski JM, Kasner MT, Yang JX, Crutchlow MF, et al. (2009). The diabetes gene Pdx1 regulates the transcriptional network of pancreatic endocrine progenitor cells in mice J. Clin. Invest. 119: 1888-1898.

Serafimidis I, Rakatzi I, Episkopou V, Gouti M, et al. (2008). Novel effectors of directed and Ngn3-mediated differentiation of mouse embryonic stem cells into endocrine pancreas progenitors. Stem Cells 26: 3-16.

St-Onge L, Sosa-Pineda B, Chowdhury K, Mansouri A, et al. (1997). Pax6 is required for differentiation of glucagonproducing alpha-cells in mouse pancreas. Nature 387: 406-409.

Wang S, Jensen JN, Seymour PA, Hsu W, et al. (2009). Sustained Neurog3 expression in hormone-expressing islet cells is required for endocrine maturation and function. Proc. Natl. Acad. Sci. U. S. A. 106: 9715-9720.

Yuan H, Li J, Xin N, Zhao Z, et al. (2010). Expression of Pdx1 mediates differentiation from mesenchymal stem cells into insulin producing cells. Mol. Biol. Rep. 37: 4023-4031. 